\title{
誘起泌乳による乳牛の泌乳能力の推定
}

\section{III. 誘起泌乳成績の検討}

\author{
内藤元 男* - 加納康彥* - 加々見恒夫 ${ }^{* *}$ - 加藤 英 輔** \\ 根本 恒** - 弥屋照夫块 - 平賀即 榆 ${ }^{* * *}$ - 香月利信*** \\ 柏木 甲吕* 中西久二***
}

( $*$ 東大農学部, **福島種畜牧場, ***北海道農試畜産部)

発情物質の少量長期投与により未交配あるいは涸乳中 のモルモット, 山羊, 牛, 霊長類に乳腺の発育ひいては 泌乳まで起ることが諸家により報告されている。そこで これを応用して内藤ら 1 ,2) は先に未交配雌山羊において 合成発情物質の投与による誘起泌乳の成績により, 正常 泌乳の諸形質が早期に相当な確かさをるつて推定でさる ことを報告した。その前後に $\mathrm{EATON}^{3)}$, 五島・大島 ${ }^{4}$ る方法では若干異なるが同様の可能性を報告している。

この問題の実用的意義は山羊よりも乳牛において大き いので山羊について見られたと同様のことが乳牛におい ても見られるかどうかを調べ, それにより正常泌乳能力 を早期に検定することの可能性, ひいては雄の後代検定 を確め得るか否かを調べるためにこの研究を始めた。先 に 7 頭での誘起泌乳成績についで5), さらに 12 頭での 誘起, 正常両泌乳間の相関括上び卵巣, 発情, 体の発育 への影響について $\left.{ }^{6}\right)$ 報告したが, 今回は誘起の成績が増 乙24 頭（一部の形質では 26 頭）となつたので誘起泌乳 そのものについて検討を加えた。

\section{実験材料および方法}

ホルスタイン種掞よび同種系牛で, 福島種畜牧場 8 頭, 北海道農試畜産部 14 頭, 東大農学部附属牧場 2 頭, 計 24 頭である。

処理方法は前と同樣, 生後 16 カ月を標準とし, 原則 として発情開始予定の 3 日前から武田薬品工業 $\mathrm{KK}$ 製の 合成発情物質オイベスチンの油溶液を実量 $5 \mathrm{mg}$ (10 万

Prediction of dairy performance of cows by the induced lactation. III. The analysis of the results of the induced lactation.

M. NAITO, *, Y. KANO*, T. KAGAMI**, E. KATO**, H. NEMOTO**, T. MIYA**. S. HIRAGA***, T. KATSUKI***, K. KASHIWAGI*** \& H. NAKANISHI***. (*Fac. Agric., Univ. Tokyo, **Fukushima Stock Farm \& $* * *$ Div. Anim. Husb., Hokkaido Agric. Exp. Sta.), Jap. J. Animal Reprod. 8, (2).
IU.) ずつ 3 日目毎に 10 回, 総計 $50 \mathrm{mg}$ (100 万 IU.) を皮下注射し, 注射開始と同時に搾乳刺激を与えた。㩁 乳は 1 日 1 回とし, 記録をとり, 搾乳停止は分婏期との 関係で個体により多少異なるが概小日量 $2 \mathrm{~kg}$ 以下とな つた場合に行なつた。乳脂率は 10 日毎に 1 回調べた。

注射開始後, 発情の徵候, 持続, 周期を外部より観察 するとともに直腸検査により卵巣の状態を調べ，処理の 影響を見た。数回発情を繰返兄しその影響が確かめられ た後，人工授精あるいは交配を行なつた。

発育は毎月 1 回体重, 体高, 体長, 胸囲などを測定し て経過を見た。

\section{実験成樍並びに考察}

（1）誘起泌乳成績 誘起処理に上る乳の分泌は注 射開始後拈よそ 10 日前後, 早いものでは 3 日位で始ま る。日量 $100 \mathrm{~g}$ を越すのは注射開始後 20 日前後である。 一般に注射を全部終ると乳量が急に増加している。5 日 間の平均で日量を出し, 泌乳曲線を画くと, 山羊の場合 と同様, 乳量が急上䄯して相当高い最高日量に達するる の, 中等度の上㫒を続けて相当高い最高日量に達するる の, 鈍感で上年が緩く, 最高日量も低いものの 3 型に大 別される。同父異母の半きょうだいのうちには同じ型に 属するものが多かつたので, 反応性はめる程度遺伝によ つて支配されていることが推測された。

乳量の多いるのでは搾乳停止はお上そ $2 \mathrm{~kg}$ 内外とな るので, 初期の $100 \mathrm{~g}$ 内外の值を加えて平均日量を出す のは意味がないから泌乳曲線より検討して最高日量 5〜 $10 \mathrm{~kg}$ のものでは 5 日間平均で $1 \mathrm{~kg}$ になつてから，2〜 $5 \mathrm{~kg}$ のものでは同じく $0.5 \mathrm{~kg}, 2 \mathrm{~kg}$ 以下のものは同じ く $100 \mathrm{~g}$ より算入することにし，それ以後 305 日以内 の記録をとつた。

なおこの誘起泌乳試験の開始時月令の範囲では開始時 の月令, 体重と乳量との相関が第 2 表に示すよ.5に低く 有意でなかつたので，この検討においては月令補正を行 
第 1 表 誘 起 泌 乳諸 形質 值

\begin{tabular}{|c|c|c|c|c|c|c|c|c|c|c|}
\hline 場所 & 頭数 & $\begin{array}{c}\text { 開 始 時 } \\
\text { 月令 } \\
*\end{array}$ & $\begin{array}{r}\text { 開始時体重 } \\
(\mathrm{kg})\end{array}$ & $\begin{array}{r}\text { 総乳量 } \\
(\mathrm{kg})\end{array}$ & $\begin{array}{c}\text { 搾乳期間 } \\
\text { (日) }\end{array}$ & $\begin{array}{r}\text { 最高日量 } \\
* \text { * (kg) }\end{array}$ & $\begin{array}{l}\text { 最高期 } \\
* \text { (日) }\end{array}$ & $\begin{array}{c}\text { 平均日量 } \\
(\mathrm{kg})\end{array}$ & $\begin{array}{r}\text { 総乳脂量 } \\
(\mathrm{kg})\end{array}$ & $\begin{array}{c}\text { 平均乳脂率 } \\
(\%)\end{array}$ \\
\hline 福 島 & 8 & $\begin{array}{r}17.1 \\
\pm 0.9\end{array}$ & $\begin{array}{r}400.9 \\
\pm 12.2\end{array}$ & $\begin{array}{r}1518.3 \\
\pm 164.1\end{array}$ & $\begin{array}{r}300.9 \\
\pm 2.0\end{array}$ & $\begin{array}{r}6.81 \\
\pm 0.67\end{array}$ & $\begin{array}{r}175.5 \\
\pm 31.8\end{array}$ & $\begin{array}{r}5.04 \\
\pm 0.53\end{array}$ & $\begin{array}{r}50.81 \\
\pm 5.22\end{array}$ & $\begin{array}{r}3.39 \\
\pm 0.16\end{array}$ \\
\hline 北海道 & 14 & $\begin{array}{r}16.1 \\
\pm 0.6\end{array}$ & $\begin{array}{r}366.1 \\
\pm 11.9\end{array}$ & $\begin{array}{r}570.0 \\
\pm 120.1\end{array}$ & $\begin{array}{r}183.1 \\
\pm 13.1\end{array}$ & $\begin{array}{r}4.64 \\
\pm 0.71\end{array}$ & $\begin{array}{r}73.3 \\
+11.2\end{array}$ & $\begin{array}{r}2.93 \\
\pm 0.54\end{array}$ & $\begin{array}{r}18.51 \\
\pm 3.86\end{array}$ & $\begin{array}{r}3.27 \\
\pm 0.06\end{array}$ \\
\hline 東大牧 & 2 & $\begin{array}{r}17.0 \\
\pm 0.7\end{array}$ & 325.0 & $\begin{array}{r}1367.3 \\
\pm 124.5\end{array}$ & 305.0 & $\begin{array}{r}7.15 \\
\pm 0.80\end{array}$ & $\begin{array}{r}136.3 \\
\pm 59.3\end{array}$ & $\begin{array}{r}4.48 \\
\pm 0.42\end{array}$ & $\begin{array}{r}51.92 \\
\pm 17.05\end{array}$ & $\begin{array}{r}3.76 \\
\pm 0.93\end{array}$ \\
\hline $\begin{array}{l}\text { 総計又 } \\
\text { は平均 }\end{array}$ & 24 & $\begin{array}{r}16.5 \\
\pm 0.4\end{array}$ & $\begin{array}{l}376.0 \\
\pm 9.1\end{array}$ & $\begin{array}{r}952.5 \\
+128.5\end{array}$ & $\begin{array}{r}232.5 \\
\pm 14.5\end{array}$ & $\begin{array}{r}5.60 \\
\pm 0.50\end{array}$ & $\begin{array}{r}112.0 \\
\pm 15.2\end{array}$ & $\begin{array}{r}3.76 \\
\pm 0.39\end{array}$ & $\begin{array}{r}32.06 \\
\pm 4.42\end{array}$ & $\begin{array}{r}3.35 \\
\pm 0.08\end{array}$ \\
\hline
\end{tabular}

（倩考） 1. 土以下の数值は S.D.

2 . * 北海道 1 , 東大 1 増, 計 26 頭

第 2 表 誘起泌乳諸形質間の相関係数

\begin{tabular}{|c|c|c|c|}
\hline $\mathrm{X}: \mathrm{Y}$ & ${ }^{\text {福 }}(\mathrm{N}: 8)^{\text {島 }}$ & 北 $\left(\mathrm{N}^{\text {海 }}: 14\right)^{\text {道 }}$ & 全 $(N: 24)^{\text {体 }}$ \\
\hline 最高日量 : 総 乳 量 & $+0.9335^{* * * *}$ & $+0.9037 * * * *$ & $+0.8652^{* * * *}$ \\
\hline “: 平均日量 & +0.5446 & $+0.9844^{* * * *}$ & $+0.8917 * * * *$ \\
\hline : 搾 乳 期 間 & +0.2803 & +0.4604 & $+0.5805^{* * *}$ \\
\hline ：最 高 期 & +0.6184 & -0.0683 & $+0.4226^{*}(26)$ \\
\hline : 総乳脂量 & $+0.7326^{*}$ & $+0.9335^{* * * *}$ & $+0.8024^{* * * *}$ \\
\hline : 平均乳脂率 & -0.5483 & -0.2128 & -0.1323 \\
\hline 総乳量: 平均日量 & $+0.9987 * * * *$ & $+0.9464 * * * *$ & $+0.9352^{* * * *}$ \\
\hline : 搾 乳 期 間 & +0.4701 & $+0.6460 * *$ & $+0.8254^{* * * *}$ \\
\hline " $\quad$ : 最 高 期 & $+0.7772^{*}$ & +0.0647 & $+0.6667^{* * * *}$ \\
\hline : 総 乳 脂 量 & +0.8980 & $+0.9960 * * * *$ & $+0.9393^{* * * *}$ \\
\hline : 平均乳脂率 & -0.3708 & -0.1874 & +0.0594 \\
\hline 搾乳期間：最 高 期 & -0.2627 & +0.3827 & $+0.6267 * * * *$ \\
\hline 総乳脂量 : 平均乳脂率 & +0.0656 & -0.1017 & +0.2730 \\
\hline 令：最高日量 & +0.1633 & $-0.0125 \quad(15)$ & $+0.1518 \quad(26)$ \\
\hline " ：総 乳 量 & +0.2351 & +0.0536 & +0.1684 \\
\hline 重：最 高 日 量 & +0.2568 & $-0.0805 \quad(15)$ & +0.1215 \\
\hline "l：総 乳 量 & +0.4016 & +0.0398 & $+0.2910 \quad(23)$ \\
\hline
\end{tabular}

\begin{tabular}{|c|c|c|c|c|c|c|c|}
\hline \multicolumn{3}{|l|}{ （備考） } & $\mathrm{n}: 6$ & $\mathrm{n}: 12$ & $\mathrm{n}: 22$ & $\mathrm{n}: 24$ & \multirow{5}{*}{ 2. 数植の横の（）の数字はそ } \\
\hline 1. & $*$ & $0.02<\mathrm{P}<0.05$ & 0.7067 & 0.5324 & 0.4061 & 0.3892 & \\
\hline & $* *$ & $0.01<\mathrm{P}<0.02$ & 0.7887 & 0.6120 & 0.4733 & 0.4545 & \\
\hline & $* * *$ & $0.001<\mathrm{P}<0.01$ & 0.8343 & 0.6614 & 0.5168 & 0.4969 & \\
\hline & $* * * *$ & $\mathrm{P}<0.001$ & 0.9249 & 0.7800 & 0.6249 & 0.6112 & \\
\hline
\end{tabular}

わず実測值のみを使用した。

かくして得た誘起泌乳の成績を第 1 表に示す。

福島と北海道とを比べると,ぞの值も福島の方が高い。 ことに総乳量では 3 倍に近く, その要因としての最高日 量も高く，搾乳期間も長い。北海道でも全個体が低いの ではなく, 少数のものは福島のもの以上を示した。標準 偏差に見られるよ5にどの形質も変異がやや大きい。こ の両者の差が何によるか明言はできないが, 福島種畜牧
場では種畜生産を目的として数代に亘り選抜が行われて きたものが供試されたに対し, 北海道農試では試験牛と して導入されていたものであるという点から遺伝的な差 があり，感受性の鈍い（時間的な敏感さでなく，刺㦸に

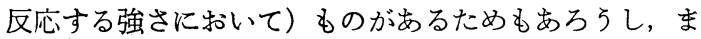
た各々の場にそれぞれ共通の自然的な環境条件と飼料や 管理法などの人為的環境条件による差もあるであろう。 な敃開始時月令で北海道の方で平均して 1 カ月若く， 
体重も小さかつたが，後に記すように乳量との間の相関 は低く,これによるとは思われない。

次に誘起泌乳の諸形質の間の単純な表型相関を調べる と第 2 表の如くである。

最高日量は総乳量, 平均日量, 総乳脂量との間汇かな り高い正の相関があり, 総乳量は平均日量, 搾乳期間, 総乳脂量との間飞高い正の相関があつた。総乳脂量は総 乳量との関係が高く, 平均乳脂率との相関は有意でなか つた。これらの関係は大体において正常泌乳の中でのこ れらの関倸関する諸報告と似た傾向を示している。
月令, 体重と最高日量, 総乳量との相関は低く, 何れ も有意でなかつたので前記のように月令補正をしなかつ たのである。

次に父親を共通にする半きようだいが 6 組 18 頭むつ たが，福島は 1 組 2 頭のみで他は北海道であつたため, 地域間の分析をせず，一括して父間父内による級内相関 法で誘起泌乳の諸形質に拈ける表型似通いの程度を算出 した。第 3 表の如くであつて何れもかなり高い值を示し た。

第 3 表 誘起泌乳諸形質の表型似通いの程度

\begin{tabular}{|c|c|c|c|c|c|c|c|c|c|c|}
\hline 形 & \multicolumn{3}{|c|}{ 質 } & \multicolumn{3}{|c|}{ 変 動 因 } & 自由度 & 平 方 和 & 平均平方和 & $\mathrm{t}$ \\
\hline 総 & 孚 & & 量 & $\begin{array}{l}\text { 父 } \\
\text { 父 } \\
\text { 全 }\end{array}$ & $\begin{array}{l}\text { 系 } \\
\text { 系 }\end{array}$ & $\begin{array}{l}\text { 間 } \\
\text { 内 } \\
\text { 体 }\end{array}$ & $\begin{array}{r}5 \\
12 \\
17\end{array}$ & $\begin{array}{l}3014368.06 \\
2123241.15 \\
5137609.21\end{array}$ & $\begin{array}{l}602873.612 \\
176936.763\end{array}$ & 0.445 \\
\hline 最 & 高 & 日 & 量 & $\begin{array}{l}\text { 父 } \\
\text { 父 } \\
\text { 全 }\end{array}$ & $\begin{array}{l}\text { 系 } \\
\text { 系 }\end{array}$ & $\begin{array}{l}\text { 間 } \\
\text { 内 } \\
\text { 体 }\end{array}$ & $\begin{array}{r}6 \\
14 \\
20\end{array}$ & $\begin{array}{r}70.2560 \\
66.7479 \\
137.0039\end{array}$ & $\begin{array}{r}11.7093 \\
4.7677\end{array}$ & 0.327 \\
\hline 最 & 焉 & & 期 & $\begin{array}{l}\text { 父 } \\
\text { 父 } \\
\text { 全 }\end{array}$ & $\begin{array}{l}\text { 系 } \\
\text { 系 }\end{array}$ & $\begin{array}{l}\text { 間 } \\
\text { 内 } \\
\text { 体 }\end{array}$ & $\begin{array}{r}6 \\
14 \\
20\end{array}$ & $\begin{array}{r}68022.08 \\
34993.47 \\
103015.55\end{array}$ & $\begin{array}{r}11337.013 \\
2499.533\end{array}$ & 0.541 \\
\hline 平 & 均 & 日 & 量 & $\begin{array}{l}\text { 父 } \\
\text { 交 } \\
\text { 全 }\end{array}$ & $\begin{array}{l}\text { 系 } \\
\text { 系 }\end{array}$ & $\begin{array}{l}\text { 間 } \\
\text { 内 } \\
\text { 体 }\end{array}$ & $\begin{array}{r}5 \\
12 \\
17\end{array}$ & $\begin{array}{l}28.8397 \\
28.8309 \\
57.6700\end{array}$ & $\begin{array}{l}5.7679 \\
2.4025\end{array}$ & 0.318 \\
\hline 平 & 均. 寽 & 脂 & 率 & $\begin{array}{l}\text { 父 } \\
\text { 交 } \\
\text { 全 }\end{array}$ & $\begin{array}{l}\text { 系 } \\
\text { 系 }\end{array}$ & $\begin{array}{l}\text { 間 } \\
\text { 内 } \\
\text { 体 }\end{array}$ & $\begin{array}{r}5 \\
12 \\
17\end{array}$ & $\begin{array}{l}0.7685 \\
0.3490 \\
1.1175\end{array}$ & $\begin{array}{l}0.1537 \\
0.0291\end{array}$ & 0.588 \\
\hline
\end{tabular}

第 4 表 泌乳誘起処理の繁殖及び発育への影響

\begin{tabular}{|c|c|c|c|c|c|c|c|c|c|}
\hline 場所 & 頭数 & $\begin{array}{l}\text { 注射開始時 } \\
\text { 月令（月） } \\
(\mathrm{A}) *\end{array}$ & 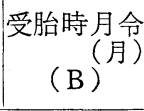 & $(\mathrm{B})-(\mathrm{A})$ & $\left|\begin{array}{c}\text { 初産時月令 } \\
\text { (月* }\end{array}\right|$ & $\mid$\begin{tabular}{c|} 
受 胎 前 \\
発情回数 \\
(含受胎時)
\end{tabular} & $\begin{array}{l}\text { 受胎までの } \\
\text { 授精回数 }\end{array}$ & $\begin{array}{c}\text { 卵巣・発情 } \\
\text { の影響 } \\
*, \text {, }\end{array}$ & $\begin{array}{c}\text { 発育への影響 } \\
*, \# \text { 井 }\end{array}$ \\
\hline 福 島 & 8 & $\begin{array}{r}17.1 \\
\pm 0.9\end{array}$ & $\begin{array}{r}21.8 \\
\pm 0.6\end{array}$ & $\begin{array}{r}4.7 \\
\pm 0.7\end{array}$ & $\begin{array}{r}30.8 \\
\pm 0.7\end{array}$ & $\begin{array}{r}7.1 \\
\pm 0.9\end{array}$ & $\begin{array}{r}0.5 \\
\pm 0.2\end{array}$ & $\begin{array}{l}-: 3 \\
\perp: 5\end{array}$ & $-: 8$ \\
\hline 北海道 & 14 & $\begin{array}{r}16.1 \\
\pm 0.6\end{array}$ & $\begin{array}{r}23.0 \\
\pm 1.5\end{array}$ & $\begin{array}{r}6.9 \\
\pm 1.0\end{array}$ & $\begin{array}{r}32.1 \\
\pm 1.6\end{array}$ & $\begin{array}{r}5.6 \\
\pm 0.9\end{array}$ & $\begin{array}{r}1.8 \\
\pm 0.6\end{array}$ & $\begin{array}{l}+: 4,+t: 6 \\
+: 4, \quad \#: 1\end{array}$ & $\begin{array}{l}-: 1, \quad+: 7 \\
+: 7\end{array}$ \\
\hline 東大牧 & 2 & $\begin{array}{r}17.0 \\
\pm 0.7\end{array}$ & $\begin{array}{r}25.0 \\
\pm 7.1\end{array}$ & $\begin{array}{r}8.5 \\
\pm 7.8\end{array}$ & 39 & $\begin{array}{r}5.0 \\
\pm 1.3\end{array}$ & $\begin{array}{r}0.5 \\
\pm 0.7\end{array}$ & $\bar{H}: 1, \quad+: 1$ & $-: 3$ \\
\hline $\begin{array}{l}\text { 総計又 } \\
\text { は平均 }\end{array}$ & 24 & $\begin{array}{r}16.5 \\
\pm 0.4\end{array}$ & $\begin{array}{r}22.8 \\
\pm 0.9\end{array}$ & $\begin{array}{r}6.3 \\
+0.4\end{array}$ & $\begin{array}{r}31.9 \\
\pm 1.0\end{array}$ & $\begin{array}{r}6.1 \\
\pm 0.6\end{array}$ & $\begin{array}{r}1.3 \\
\pm 0.4\end{array}$ & $\begin{array}{l}-: 4, \quad+: 10 \\
+1: 6, \quad H: 4 \\
H: 2\end{array}$ & $\begin{array}{l}-: 12,+: 7 \\
+: 7\end{array}$ \\
\hline
\end{tabular}

（備考） 1. 土は標準偏差

2. * は北海道 1 , 東大 1 増, 計 26 頭

3. ***北海道 1 , 東大 1 減のため, 計 22 頭

（末分婏）

これが全て異なる環境下であれば，環境の影響が無視 できるし，また福島での組数がもつとあれば地域による 差の影響も算出でき, 遺伝力の算出も可能であるが現状
4. \#-：影響なし $\perp$ : 周期に弱い䚓乱 十：短期の 発情休止, 弱発情 $\#$ : 長期の発情休止, 弱発情 持続 + : : 卵胞囊腫

5.
一：影響なし +：緩い成長 十：短期の成長停止 H : 長期の成長停止 $\#$ : 減少
ではそれはできない。しかしこれらの形質がある程度遺 伝によつて支配されていることは推定できよう。未成熟 期のマウスにおけるオイベスチンによる乳腺発育反応の 
遺伝力は $0.51\left(\right.$ 水井ら ${ }^{7)}$ ) であつた。ここでとり上げた 乳量などの形質にはさらに環境による影響が強いことは 考えられるが, 永井らの成績は遺伝要因の関与を示唆す るものであろう。

（2）卵巣, 発情及び発育への影響 これらの成績 を一括して第 4 表に示す。

受胎時月令, 初産時月令が一般よりも若干遅れている。 しかしこれは卵巣, 発情への影響を見るために授精せず に観察したことにもよる。すなわち受胎前の発情経過回 数（受胎時の発情も含む）は平均 6.1 回となつており, それから受胎までの授精回数の平均 1.3 回を引いた 4.8 回が発情の観察回数の平均であるわけで, 後仁記すよう に周期の延びたものがあるために月数に比べて回数が少 なくなつている。この受胎までの授精回数 1.3 回は一般 と比べて多いものではない。

卵巣扣よび発情への影響の程度については, 影響の全 くないものも 4 頭あつたが, 多くはなんらかの影響を受 けている。便宜のためその程度により分類してみたが, 弱いものでは注射開始直後の発情持続の延長, 周期の一 時的な短縮のあつたものが 10 頭, 短期間の異常として 1 周期ぐらい発情が休止したり，また中卵胞による弱発 情持続が短期間あつたものが 6 頭あつたが，これらは何 れも放置して正常に復している。2 カ月ぐらいの長期に わたる異常としては発情の休止が 2 頭, 中卵胞による弱 発情持続が 2 頭あるが，これは思牡症ではなく，3頭は 放置して正常に復し，1頭はプロラン $5000 \mathrm{IU}$. の 1 回 処理で恢復した。卵胞雯腫は 2 頭むつたが 1 頭は破碎と プロラン処理で恢復し, 受胎分婏したが正常泌乳中に再 発している。この牛の母, 妹共に自然に襄腫を発してい るので遺伝的要因の関与も想像される。CASIDA \& CHAPMAN $^{8)}$ とよると卵胞囊腫の遗伝力は 0.43 と推定し ておりかなり高いものである。他の 1 頭はプロラン 5000 IU. 2 回処理で即巣はよくなつたが子宮の収縮不良で受 胞せず淘汰された。

第 4 表に見られるよ5に繁殖への影響も福島では軽微 であり, 北海道でやや強い。それには遺伝的な要因と共 に環境要因の関与も考兄られる。季節の影響, 特にその の一つとしての粗飼料中の発情物質などによる増強作用 も考兄られるが，注射開始の月は福島では $2,3 ， 4,5$, 12 月と広く分布しているが, 影響が軽微なので問題はな い。北海道では春一夏開始が多いのではつきりしたこと はいえないが, 十は 4 月 1 頭, 5 月 3 頭, 十は 6 月 3 頭, $8,9,11$ 月各 1 頭, + は 4 月末 1 頭, 6 月 2 頭, 7 月 1 頭, 卅は 5 月 1 頭で, 影響が強く出たのは晚春から初
夏に開始されたものに多い感がある。

発育への影響は体重, 体高, 体長, 胸囲についてホル 協 ${ }^{9}$ の発育標準に照応して曲線から検討したが，影響の 認められないもの 12 頭, 一時的に上年の緩かになつた もの 7 頭, 短期間停頓の見られたもの 7 頭で主に胸囲, 体長ひいては体重に見られた。しかしこの影響が長期に 亘つて成熟時まで続いて残つたものはない。発育への影 響は福島, 東大牧には全くなく, 北海道のみに影響が出 ている。このことは主に環境要因に因ることを推定させ る。何れにせ上発育への影響は軽微で十分防ざうるもの と考光られる。

\section{要約}

合計 100 万 IU. のオイベスチン処理による誘起泌乳 の成績について検討を加えた。福島種畜牧場, 北海道農 試畜産部, 東大農学部牧場の 3 カ所 24 頭のホルスタイ ン及び同種系牛について泌乳, 繁殖, 発育状況を調べ た。総平均で総乳量 $952.5 \mathrm{~kg}$, 最高日量 $5.60 \mathrm{~kg}$, 平均 乳脂率 $3.35 \%$ であつた。福島と北海道との間に各形質 とも差があり, 福島で高かつた。遺伝的な要因と共に夫 々の場所内で共通な環境要因の影響のあることが䙾われ た。

泌乳諸形質間の相関を調べ，さらに半きようだいでの 級内相関で表型似通いの程度を算出したが $0.318 〜 0.588$ でかなり高い値を得た。

繁殖への影響は, 強く出た場合も少数あつたが, 大部 分は憂らべきものとはいえない。発育への影響は軽微で あつた。(1962.4.16 受付)

\section{文献}

1) 内藤 $($ 元) ・横山 (昭) - 吉岡 (善) - 井出 (泰) ・ 横山 (孝) : 育種雑, 1, 223, 1952.2 2) 内藤 (元) - 横 山（昭）・吉岡（善）・横山（孝）・横塚 (豊): 育種雑, 3, (2), 13, 1953. 3) EATON, O. N., A.L. SimmoNS, J.F. SYKES, T.R. WRENN \& S.R. HALL :J. Dairy Sci., 36, 1089, 1953. 1955.4 4) 五島（孝） 大島 $($ 正) - 農技研報 $\mathrm{G}(10), 91,1955.5)$ 内藤 $($ 元) - 大久保 (䒨) - 根本 (恒). 阿部 (章) - 鈴木 (章) -上 月(操) - 桜井 (允) - 香月 (利) : 本誌, $1,127,1955$. 6) 内藤 (元) - 加納 (康) · 大久保 (摸) - 根本 (恒) 塚本 (不) - 桜井 (允) - 香月 (利) - 柏木 (甲)中西 (久) : 日畜会報, $31,172,1960.7)$ 永井（次）・吉田(元) -内藤（元）: 日音会報, 28, 287, 1957. 8) CASIDA, L.E. \& A.B. ChAPMAN : J. Dairy Sci., 34, 1200, 1951.9）ホル協: ホルスタイン種牛の正常発育曲線, 1959. 


\section{Summary}

Twenty four heifers of Holstein in 3 stations were administered with synthetic estrogen "Euvestin", one million I. U. in total, and their induced lactation, reproduction and growth were examined.

The total milk yeild was $952.5 \mathrm{~kg}$., the peak yield $5.60 \mathrm{~kg}$., and milk fat $3.35 \%$ in average. There were differences in results between stations, and it suggested that not only genetic factors but also environmental factors played an important role.

The coefficients of correlation between dairy characters were calculated and the phenotypic resemblance between half sibs in dairy characters showed fairly high value, $0.318-0.588$.

The influence of the treatment upon reproduction was not so much excepting few cases, and that upon growth was slight. 